\title{
Education Research on College Students' Innovation and Entrepreneurship under the Background of Internet +
}

\author{
Sulan Wang', Yuqing Zhang ${ }^{2}$ \\ ${ }^{1}$ Entrepreneurship College of Xijing University, Xi'an, Shaanxi Province, China \\ ${ }^{2}$ Northwest University, Xi'an, Shaanxi Province, China
}

Keywords: "Internet +"; college students; innovation and entrepreneurship

Abstract: "Internet + " as a new economic form, under the encouragement of "mass entrepreneurship, innovation", provides new opportunities for college students to innovate and start a business. College students have a clear advantage in starting the Internet era because of their high familiarity with the Internet. The government should give policy support to college students' Internet-based entrepreneurship. Colleges and universities should form a sound entrepreneurship curriculum system and encourage college students to actively participate in high-level Internet entrepreneurship competitions.

\section{Introduction}

As early as the summer Davos Forum in September 2014, Premier Li Keqiang publicly issued the call for "mass entrepreneurship and innovation". Later, Premier Li Keqiang explained this key again. Words, and pointed out that the Internet is a new tool for mass entrepreneurship and innovation. In the March 2015 government work report, Premier Li Keqiang first proposed the "Internet + " action plan: formulate an "Internet + " action plan to promote the integration of mobile Internet, cloud computing, data, Internet of Things and modern manufacturing, and promote e-commerce, The healthy development of industrial Internet and Internet finance has led Internet companies to expand into the international market.

\section{College students' innovation and entrepreneurial opportunities under the background of "Internet +"}

\subsection{The size of denizens continues to climb.}

As of June 2016, the number of denizens in China reached 710 million. The total number of new denizens increased by 21.32 million in the first half of the year, with a growth rate of $3.1 \%$ in the first half of the year, which was higher than the growth rate in the second half of 2015 . The Internet penetration rate was $51.7 \%$, an increase of 1.3 percentage points from the end of 2015 . The number of mobile Internet users reached 656 million, an increase of 36.56 million compared with the end of 2015. The proportion of Internet users using mobile phones has increased from $90.1 \%$ at the end of 2015 to $92.5 \%$, and mobile phones dominate the Internet. 


\subsection{College students' competitive disadvantages are reduced.}

The reduction of college students' competitive disadvantages mainly includes six reasons: "S1 entrepreneurship gives people the opportunity to grow and develop, which is a good choice". "S2 entrepreneurial process can make me gradually become the strongman who dominates me", "S3 is in business under unfavorable conditions, I can constantly challenge myself and realize the value of life." "The low starting point of S4 is the driving force for me to make continuous efforts to start my own business." "S5 low starting point, although it is hard, it makes me bigger. "The space for growth and development", "S6 I want to use my professional knowledge, take root in the countryside, and drive my hometown father to get rich." The results of the survey are shown in Table 1

Tab.1 Survey results of entrepreneurial motivation factors

\begin{tabular}{cccccc}
\hline & $\begin{array}{c}\text { Very } \\
\text { inconsistent }\end{array}$ & not inconsistent & unclear & $\begin{array}{c}\text { in } \\
\text { conformity }\end{array}$ & $\begin{array}{c}\text { very } \\
\text { consistent }\end{array}$ \\
\hline S1 & $0.50 \%$ & $2.67 \%$ & $11.00 \%$ & $43.00 \%$ & $21.50 \%$ \\
S2 & $0.50 \%$ & $3.00 \%$ & $17.00 \%$ & $52.33 \%$ & $27.67 \%$ \\
S3 & $0.50 \%$ & $3.33 \%$ & $22.67 \%$ & $53.00 \%$ & $20.67 \%$ \\
S4 & $1.33 \%$ & $9.00 \%$ & $21.67 \%$ & $51.33 \%$ & $17.00 \%$ \\
S5 & $1.00 \%$ & $2.00 \%$ & $16.00 \%$ & $58.33 \%$ & $22.33 \%$ \\
S6 & $2.33 \%$ & $14.44 \%$ & $36.00 \%$ & $34.33 \%$ & $13.00 \%$ \\
\hline
\end{tabular}

Entrepreneurship in the traditional industry has high requirements for funds, qualifications and resources, and it is difficult for college students who are starting a business to compete with experienced entrepreneurs. However, the industry sector of "Internet + " is undergoing rapid changes, and a perfect system has not yet been formed. Both college students and other groups are in the stage of exploration, which inevitably narrows the gap between college students and experienced entrepreneurs.

\section{College students' innovation and entrepreneurial advantages under the background of "Internet +"}

\subsection{Growing up in the Internet era, I understand the network very well.}

Born in the post-95s, contemporary college students are the latest generation with the growth of the Internet. Their lives are accompanied by the Internet. They are comfortable with the use of the Internet. They are also proficient in using the Internet to obtain a variety of information. These students have more comprehensive knowledge, a broader vision and even more experience. At the same time, they have keen observation, strong information search ability and ability to predict future trends, enabling them to find the Internet more accurately.

\subsection{Execution is strong, dare to dare to do.}

Through some social phenomena and social reports, it is not difficult to see that contemporary college students have strong opinions and executive powers. This is evident from the phenomenon of "interval years" that has arisen in recent years. Many college students now choose this way after graduation. Traveling and studying in a vacuum period, to appreciate life, is completely different from the previous graduation-employment, and even the traditional practice of not even appearing 
in the middle of a month. Treating problems with their own opinions and daring to dare to give them the strongest action, making them more energetic in the process of innovation and entrepreneurship.

\subsection{Advocating open management and disgusting the old system.}

For current college students, the old management system is increasingly unable to adapt to their individual needs. In the face of work, college students often prefer a more relaxed working environment, advocating Western open management and flexible systems, hoping to fully arrange their time and work plans. These dislikes of restraint are also important reasons for their stepping out of entrepreneurship. Of course, the recognition of the chosen industry also allows them to give a hand to the set goals. Based on the above three points, contemporary college students have three qualities that are important for entrepreneurs, namely, acumen, mobility and open attitude, which can help them to observe entrepreneurial opportunities and bravely put them into practice.

4. The path of college students' innovation and entrepreneurship under the background of "Internet +"

\subsection{Strengthening support in policy.}

In recent years, various policies have been introduced to encourage college students to start their own businesses. College students can enjoy tax incentives and financial support for their own business. However, some of the policies have not yet established the corresponding supporting rules, and in practice, there will be problems in which the policy effectiveness is not fully utilized.

\subsection{Improve the cultivation system of innovative and entrepreneurial talents.}

First of all, improve the system of innovation and entrepreneurship in colleges and universities. Colleges and universities with conditions should set up a teaching and research section for innovation and entrepreneurship, hire and train professional entrepreneurial teachers to teach courses in this area, and improve the system of innovation and entrepreneurship. Taking the college as a group to compare the main factors of college students' self-employment cognition factors, and conduct a t test to judge. The results are shown in Table 2.

Tab.2 Professional t test of cognitive factors of college students' self-employment

\begin{tabular}{ccccccc}
\hline & College & average & $\begin{array}{c}\text { standard } \\
\text { deviation }\end{array}$ & $\mathrm{t}$ & $\mathrm{df}$ & $\mathrm{P}$ \\
\hline $\begin{array}{c}\text { Environmental } \\
\text { integration } \\
\text { ability }\end{array}$ & $\begin{array}{c}\text { Economics and } \\
\text { Management } \\
\text { Major }\end{array}$ & 16.556 & 1.991 & 0.981 & 296 & 0.327 \\
& $\begin{array}{c}\text { Non-administrative } \\
\text { major } \\
\text { Business }\end{array}$ & 16.808 & 2.423 & & & \\
$\begin{array}{c}\text { Major in } \\
\text { Purposes } \\
\text { Manomics and } \\
\text { Management } \\
\text { Non-administration } \\
\text { major }\end{array}$ & 23.087 & 2.822 & 0.578 & 290 & 0.564
\end{tabular}

The results of the t-test showed that there was no difference in the level of environmental integration, entrepreneurial purpose and leadership communication skills among the students of the 
School of Economics and Management. Environmental integration ability (t $(296)=0.981, \mathrm{P}=0.327$ ); entrepreneurial purpose $(\mathrm{t}(290)=0.578, \mathrm{P}=0.564)$; leadership communication ability ( $\mathrm{t}$ (296) $=1.747, \mathrm{P}=0.082$ ) factor difference Not obvious.

\subsection{Adhere to the holding of high-level innovation and entrepreneurship competition.}

From May to October 2015, the first China Internet + University Student Innovation and Entrepreneurship Competition were co-sponsored by the Ministry of Education and relevant ministries and commissions and the Jilin Provincial People's Government. The competition attracted 31 provinces (municipalities, autonomous regions) and Xinjiang Production and Construction Corps 1878. The 57,253 teams of the university signed up and submitted 36,508 project projects, involving more than 200,000 students, and driving millions of college students to invest in innovation and entrepreneurship. The competition lasted for more than five months, and the scale basically covered all provinces and cities across the country. The technical content of the entries was high, far exceeding the various innovation and entrepreneurial competitions of different scales in the past.

\section{Summary}

In the era of "Internet +", governments and universities need to study and adapt to the new changes, new features, and new trends of college students' entrepreneurial will, entrepreneurial needs, and entrepreneurial forms in the context of the Internet, and timely adjust and correct untimely measures and policies to truly support college students. Entrepreneurial normalization, improve the effectiveness of entrepreneurial support. Colleges and universities with conditions should set up a teaching and research section for innovation and entrepreneurship, hire and train professional entrepreneurial teachers to teach courses in this area, improve the innovation and entrepreneurship curriculum system, and adhere to the high-level innovation and entrepreneurship competition to continuously improve the innovation and entrepreneurship of college students.

\section{References}

[1] Ding R, Finance amp A. Research on the Innovation and Entrepreneurship Education Model of College Students under the Background of Informationization [J]. Journal of Hubei Correspondence University, 2017.

[2] Yu S U, Xingxing L I, Jingxian H U. Research on the Strategy of Enhancing College Students' Innovative and Entrepreneurial Ability under the Background of Targeted Supply[J]. Journal of Changsha University, 2017.

[3] Gao H, Qiu Z, Liu Z, et al. Research and Practice on College Students' Innovation and Entrepreneurship Education[C]// International Conference of Young Computer Scientists, Engineers and Educators. Springer, Singapore, 2016:36-44. 